\title{
Morphological and growth responses to water stress of two sub- populations of Bromus pictus from soils with contrasting water availability
}

\author{
Respuestas morfológicas y de crecimiento al estrés hídrico de dos subpoblaciones de \\ Bromus pictus provenientes de suelos con contrastante disponibilidad de agua
}

\author{
JOSÉ L. ROTUNDO*, PABLO A. CIPRIOTTI \& PEDRO E. GUNDEL
}

\begin{abstract}
Cátedra de Ecología, Instituto de Investigaciones Fisiológicas y Ecológicas Vinculadas a la Agricultura (IFEVA), Departamento de Recursos Naturales y Ambiente, Facultad de Agronomía, Universidad de Buenos Aires/ Consejo Nacional de Investigaciones Científicas y Técnicas (CONICET), Avenida San Martín 4453, (C1417DSE), Buenos Aires, Argentina;

*e-mail for correspondence: rotundo@agro.uba.ar
\end{abstract}

\begin{abstract}
We studied morphological and growth responses to drought of two sub-populations of Bromus pictus from communities with soils with different water availability from the Patagonian steppe. After a process of acclimatization common to both sub-populations, individuals from both sub-populations were subjected to three levels of water availability during 44 days. Independently of the water availability treatment, the subpopulation from the community of high soil water availability showed higher aboveground relative growth rate (RGR) and higher leaf size (area and weight) compared to the sub-population from the community of low soil water availability. These results prove the expected evolution of higher growth rates and leaf sizes in resource rich environments. The sub-population from the community with low water availability also showed a higher tillering rate and a more prostrate morph than the sub-population from the community with high water availability. A higher number of small tillers may be a useful strategy for a quick response to water inputs and for distribute the risk of drought-induced mortality. A more prostrate morph may also present advantages like reducing the area exposed to dry air. The results obtained showed that soil heterogeneity may promote genetic variation. We were unable to detect statistically significant interactions between population and water availability treatments. The genetic variation found between the populations may be useful to develop breeding programs of a native species and may also increase the evolutionary potential of a native species to adapt to environmental changes.
\end{abstract}

Key words: arid lands, drought, ecotypes, genetic variation, soil depth.

\section{RESUMEN}

Nosotros estudiamos respuestas morfológicas y de crecimiento a la sequía para dos subpoblaciones de Bromus pictus provenientes de comunidades con suelos de distinta disponibilidad de agua en la estepa patagónica. Luego de un proceso de aclimatización común a ambas subpoblaciones, individuos de cada subpoblación fueron sometidos a tres niveles de disponibilidad de agua durante 44 días. Independientemente del nivel de disponibilidad hídrica, la subpoblación proveniente de la comunidad con mayor agua disponible exhibió una mayor tasa de crecimiento relativa aérea (RGR) y mayor tamaño foliar (área y peso) comparado con la subpoblación proveniente de la comunidad con menor agua disponible. Estos resultados prueban la evolución esperada de mayores tasas de crecimiento y tamaños de hoja en aquellos ambientes ricos en recursos. La subpoblación proveniente de la comunidad con menor agua disponible también exhibió una mayor tasa de macollaje y un hábito de crecimiento más postrado que la subpoblación proveniente de la comunidad con mayor agua disponible. Un mayor número de macollos pequeños puede ser una estrategia útil para una rápida respuesta a los pulsos de agua y para distribuir el riesgo la muerte inducida por sequías. Un hábito de crecimiento más postrado puede también presentar ventajas tales como reducir el área expuesta al aire seco. Los resultados obtenidos demuestran que la heterogeneidad del suelo puede promover variación genética, aunque no permitieron detectar interacciones estadísticamente significativas entre los factores vinculados con las poblaciones y la disponibilidad de agua. La variación genética encontrada entre las poblaciones puede ser útil para desarrollar programas de mejoramiento e incrementar el potencial evolutivo de una especie nativa para adaptarse a cambios ambientales.

Palabras clave: ecotipos, profundidad del suelo, sequía, tierras áridas, variación genética. 


\section{INTRODUCTION}

Genetic variability may represent a key attribute in species ability to adapt to spatial heterogeneity (Endler 1986, Linhart \& Grant 1996). Studies of adaptations of subpopulations of native species to local microenvironments in the same regional climate would be especially useful in understanding the role of landscape heterogeneity in the population genetic structure. Different environmental conditions like exposure to sun, height above sea level, and soil heterogeneity, like variation in depth or texture, may generate different selection pressures that lead to genetic differentiation (Linhart \& Grant 1996). This kind of studies may also be useful in predicting evolutionary responses of populations to global changes (Bradshaw \& McNeilly 1991, Etterson \& Shaw 2001). A population with sub-population genetic differentiation due to environmental spatial heterogeneity has a higher evolutionary potential to adapt to new climatic scenarios (Etterson \& Shaw 2001). The study of genetic differentiation in native species may also be useful to develop breeding programs of native plants for restoration of degraded lands (Theunissen 1997, M'Seddi et al. 2002). The existence of genetically improved native populations in some trait of interest may accelerate the process of re-vegetation (Jones \& Johnson 1994). In the present paper, morphological and growth responses to drought of two sub-populations of a native perennial grass from communities exposed to different water availability have been evaluated.

The occidental district of the Patagonian steppe presents two contrasting communities associated to different soil types ("deep-soil" and "shallow-soil" communities) (Golluscio et al. 1982). The dominant "deep-soil" community corresponds to sandy soil with more than $50 \%$ pebbles. There is a calcareous layer approximately $0.6 \mathrm{~m}$ deep (Paruelo et al. 1988). In this community, grass rooting is at least 0.3 $m$ deep (Soriano et al. 1987). The "shallowsoil" community is found in spots of different size in a matrix of "deep-soil" community. Soils of this community have an upper layer of $0.05 \mathrm{~m}$ of sandy texture on top of a $0.1 \mathrm{~m}$ layer of sandy clay texture that prevents root penetration (Golluscio et al. 1982). This reduces the availability of water and increases the length of drought periods. Plant populations may respond to drought by phenotypic plasticity or adaptation (Silvertown \& Doust 1993). This environmental heterogeneity has the potential to influence the distribution of genetic variation among sub-populations through several evolutionary processes, including natural selection. The hypothesis underliyng this paper is that, whether natural selection is the main evolutionary process shaping the distribution of genetic variation in the Patagonian steppe, sub-populations from communities having lower water availabiliy would present traits related to a higher success under drought condition compared with subpopulations from communities having high water availabiliy. Otherwise, sub-populations from high water availability communities would have more growth potential than subpopulations from communities having lower water availabiliy.

The success of plants under drought depends on the growth potential and/or the tolerance to stress (Hochwender et al. 2000, Stowe et al. 2000). These two components can be visualized when plotting some variable related to fitness (e.g. biomass) across a stress gradient (e.g. increasing levels of drought), often called a reaction norm. The biomass attained when stress is zero (vizualised as the y-intercept) represents the growth potential (Sultan 2000, Sarkar \& Fuller 2003). For example, if one population has a higher $y$ intercept compared to other it means that the first presents a higher growth potential than the later. Otherwise, the slope of this relation represents the tolerance to stress. For example, a population that reduces growth lesser than other when stress is increasing has higher tolerance compared to the later. Extreme reaction norms are showed in Fig. 1, where success in drought (e.g. biomass attained in the highest stress level) is determined entirely by tolerance (Fig. 1A) or entirely by growth potential (Fig. 1B) (Hochwender et al. 2000). Figure $1 \mathrm{C}$ shows a hypothetical situation in which selection by drought may favor the less tolerant sub-population (sub-population 1).

The reaction norm analysis is applied to compare different species, populations, subpopulations or even individual genotypes. In this paper we applied this approach to compare 

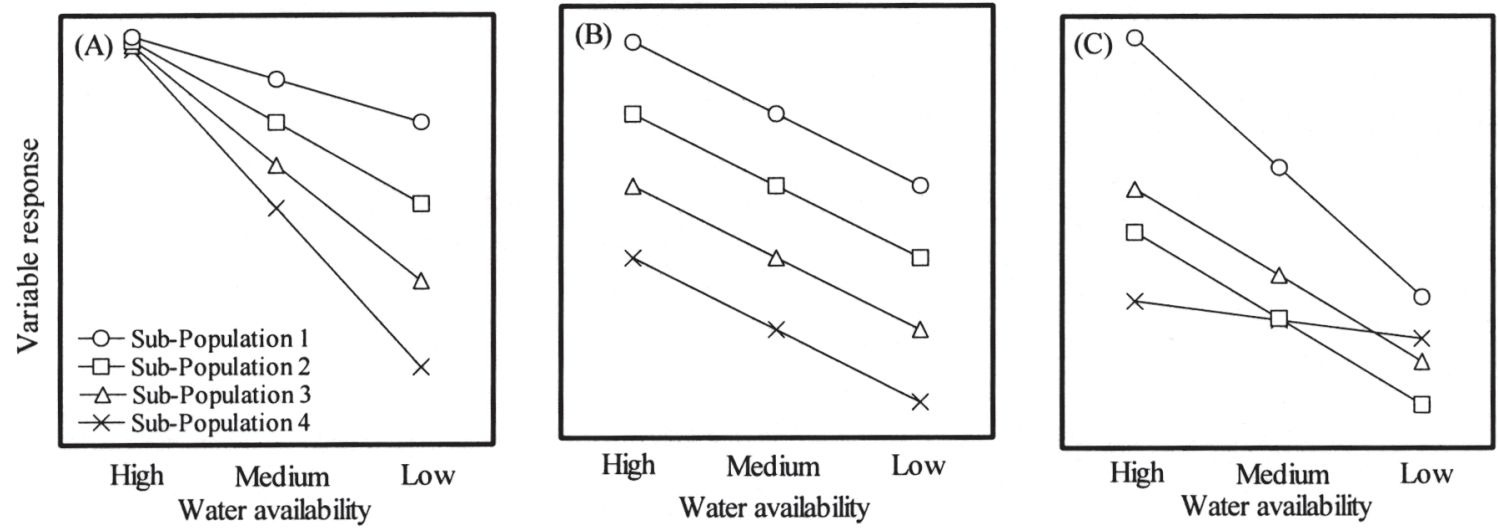

Fig. 1: Fitness components in drought in three hypothetical situations. (A) and (B) correspond to extreme situations. In (A) the subpopulations did not differ in potential growth, and fitness in drought depends entirely on tolerance. In (B) the subpopulations did not differ in tolerance, and fitness in drought depends entirely on potential growth. (C) corresponds to a particular case in which the less tolerant subpopulation (1) had higher fitness in drought than the most tolerant subpopulation (4). Graphs modified from Hochwender et al. (2000).

Componentes del "fitness" (una medida de la aptitud ecológica) en sequía para tres situaciones hipotéticas. (A) y (B) corresponden a situaciones extremas. En (A) las subpoblaciones no difieren en su potencial de crecimiento y el "fitness" en sequía depende solamente de la tolerancia. En (B) las subpoblaciones no difieren en tolerancia y el "fitness" en sequía depende solamente del crecimiento potencial. (C) Corresponde a un caso particular en cual la subpoblación menos tolerante (1) tiene mayor "fitness" en sequía que la subpoblación más tolerante (4). Las figuras fueron redibujadas a partir de Hochwender et al. (2000).

two sub-populations of Bromus pictus, a native perennial grass of high palatability which is threatened by sheep overgrazing (Aguiar et al. 1999) ${ }^{1}$. Increasing our knowledge of its ecophysiology and genetic variation will contribute to develop breeding programs for revegetation. The main objective of our work was to evaluate the responses to drought of two subpopulations of Bromus pictus from "deep-soil" and "shallow-soil" communities. In order to evaluate these responses, a common garden experiment was performed in which water availability was manipulated.

\section{MATERIAL AND METHODS}

\section{Description of communities}

Individuals of Bromus pictus (from now on Bromus) were sampled from the Instituto Nacional de Tecnología Agropecuaria (INTA),

\footnotetext{
1 AGUIAR MR, PA CIPRIOTTI, WB BATISTA \& AC PREMOLI (1999) Viabilidad de poblaciones de gramíneas patagónicas en peligro de extinción por sobrepastoreo. Abstracts of the IXX Reunión Argentina de Ecología, Tucumán, Argentina, $220 \mathrm{pp}$.
}

Experimental Field Station at Río Mayo, Chubut, Argentina (45 $41^{\prime}$ S, $70^{\circ} 16^{\prime}$ W, 500 m of altitude). Mean annual precipitation for a 37 -year record is $152 \pm 44 \mathrm{~mm}$, with $>70 \%$ of the precipitation occurring in fall-winter (Jobbágy et al. 1995). Mean annual temperature is $8.1{ }^{\circ} \mathrm{C}$ with monthly mean values ranging from $2{ }^{\circ} \mathrm{C}$ (July) and $14{ }^{\circ} \mathrm{C}$ (January) (Beltrán 1997).

Vegetation corresponds to the occidental district of the Patagonian steppe (Soriano 1983). The typical community ("deep-soil" community) is co-dominated by grasses and shrubs, which cover 25 and $12 \%$, respectively, and contribute more than $96 \%$ of the total plant biomass (Fernández et al. 1991, Golluscio \& Sala 1993, Jobbágy \& Sala 2000). The patch structure of the community is characterized by shrubs surrounded by a grass ring (Soriano et al. 1994, Aguiar \& Sala 1999). The dominant grass species are Stipa speciosa Trin. Et Rupr., Poa ligularis Nees ap. Steud., Stipa humilis Vahl and Bromus pictus Hook. The dominant shrubs species are Senecio filaginoides AD., Mulinum spinosum (Cav.) Pers. and Adesmia campestris (Rendle) Skottsb. Forbs contribute less than $1 \%$ to plant cover; however species 
richness is higher than in shrubs or grasses (Golluscio \& Sala 1993). For more than 100 years, sheep have been the main herbivore due to extensive grazing for wool and meat production; stocking rates ranges between 0.2 to 0.4 sheep ha-1 (Soriano 1983, Golluscio et al. 1998, 1999).

There is also a less typical community ("shallow-soil" community) that appears in the form of spots (that vary from 20 to $100 \mathrm{~m}$ diameter) immersed in a matrix of "deep-soil" community. The "shallow soil" community is less dominated by the perennial grasses mentioned above and more by the shrubs Nassauvia glomerulosa (Lag.) Don, Chuquiraga aurea Skottsberg and Chuquiraga kingii Ball (Golluscio et al. 1982). This community is dominant in the more arid regions located to the east (central district) (León et al. 1998).

The "shallow-soil" community is considered to be more xeric than the "deep-soil" community. Grass roots reach a depth of at least $0.3 \mathrm{~m}$ in the "deep-soil" community (Soriano et al. 1987). Shrub roots in the "shallow-soil" community do not penetrate the clay layer (Golluscio et al. 1982). Soil water storage in the layer explored by grass roots is $19.3 \mathrm{~mm}$ in the "deep-soil" community and 3.5 $\mathrm{mm}$ in the "shallow-soil" (calculated from Golluscio et al. 1987)2. Furthermore, net primary productivity is $57 \pm 5.2 \mathrm{~g} \mathrm{~m}^{-2} \mathrm{yr}^{-1}$ and $21.5 \pm 3.5 \mathrm{~g} \mathrm{~m}^{-2} \mathrm{yr}^{-1}$ for "deep-soil" and "shallow-soil" communities respectively (Golluscio et al. 1987).

\section{Experiment description}

Bromus genets were collected from two different stands of "deep-soil" $(\mathrm{n}=6)$ and "shallow-soil" ( $\mathrm{n}=6)$ sub-populations in April 2001. The diameter of spots of "shallowsoil" community was approximately $100 \mathrm{~m}$. Genets were at least $3 \mathrm{~m}$ apart from each other. The genets were clonally multiplied in $1.5 \mathrm{~L}$ pots at an open greenhouse at the Instituto de investigaciones Fisiológicas y

2 GOLLUSCIO RA, JM PARUELO \& MR AGUIAR (1987) Relaciones suelo vegetación en distintos ambientes del sudoeste de Chubut. Abstracts of the la XIII Reunión Argentina de Ecología, Bahía Blanca.
Ecológicas Vinculadas a la Agricultura (IFEVA), Universidad de Buenos Aires $\left(34^{\circ} 35^{\prime}\right.$ S, 58 $29^{\prime}$ W). Pots were filled with sand and watered with $25 \mathrm{~mL}$ Hoagland solution once a week and with water as needed for plant growth without any water limitation. During the fourth month, the genets were clonally multiplied again and grown for two additional months. Four ramets from each genet were randomly selected. One of these ramets from each genet was harvested as the time zero measure (six ramets from "deepsoil" and six from "shallow-soil"). The other three ramets from each genet were randomly assigned to water availability treatments. At the time of the treatments, the contribution of original tissue of plants was insignificant since most of the tissues of final plants were originated in the common garden. The mean temperature in the open greenhouse during experiment was $21.8^{\circ} \mathrm{C}$, ranging from 10.1 to $34.4{ }^{\circ} \mathrm{C}$. The mean of PAR radiation was 35.1 mol m${ }^{-2}$ day $^{-1}$, ranging from 2.9 to $55.4 \mathrm{~mol} \mathrm{~m}^{-}$ ${ }^{2}$ day $^{-1}$. The mean relative humidity was 71.4 $\%$, ranging from 48.8 to $91.7 \%$.

Drought treatments were imposed by watering to get three ranges of gravimetric water availability: 80-90 \%, 50-60\% and 20-30 $\%$ of field capacity. The amount of water needed to achieve each gravimetric water content was determined by weighting pots at field capacity $\left(\mathrm{W}_{\mathrm{FC}}\right)$ and pots with sand completely dried at $80{ }^{\circ} \mathrm{C}$ during $72 \mathrm{~h}\left(\mathrm{~W}_{\mathrm{D}}\right)$. The difference $\mathrm{W}_{\mathrm{FC}}-\mathrm{W}_{\mathrm{D}}$ corresponds to the weight of water at field capacity $(100 \%$ of water availability). The three ranges were determined by linear extrapolation according to the relationship between gravimetric water and percentage of water capacity. Pots were weighed daily and when pot weight reached the lower value of the target range, water was added to reach the higher level. Hoagland solution was applied instead of water until the doses of $25 \mathrm{~mL}$ Hoagland solution per week was reached.

The individuals were harvested at day 44 . Morphological variables measured were shoot biomass, root biomass (0-10 $\mathrm{cm}$ deep and 11-20 $\mathrm{cm}$ deep), number of tillers, tiller insertion angle, leaf area and leaf weight. Tiller insertion angle was measured as degrees from the horizontal with a plastic protractor. Shoot biomass is positively related with seed 
production $\left(\mathrm{R}^{2}=0.91, \mathrm{P}<0.01\right.$, Rotundo \& Aguiar unpublished data). Leaf area was measured by scanning and counting pixels. As described above, the ramets harvested at time zero of each genet of each sub-population were used to measure the relative growth rate (RGR), as a growth variable calculated: $\mathrm{RGR}=$ $\left(\operatorname{Ln}\right.$ (biomass $_{\text {final }}$ - biomass initial $\left._{\text {in }}\right) /$ duration of experiment (days)) (Hunt 1990).

The experimental design was factorial with water availability (high, medium, low), subpopulations ("deep soil" and "shallow soil") and genets (six from "deep soil" and six from "shallow soil") as factors. A general linear model was used with genets nested within subpopulations (Montgomery 1997) as,

$\mathrm{Y} i j k l=\mu+\mathrm{W} i+\mathrm{S} j+\mathrm{G}(\mathrm{S}) k(j)+\mathrm{WS} i j+e i j k l$

where $Y_{i j k l}$ represents the variable response (aerial biomass, leaf area, and so on) for the $l^{\text {th }}$ observation (plant) from the $k^{\text {th }}$ genet, $j^{\text {th }}$ subpopulation and $i^{\text {th }}$ water treatment; $\mu$ is the general mean; $W_{i}$ indicates the three different water availability levels $(i) ; S_{j}$ represents the two different sub-populations $(j) ; G(S)_{k(j)}$ represents the different genets nested within each sub-population $(k) ; W S_{i j}$ represents the interaction term between water availability and sub-populations; and finally $e_{i j k l}$ indicates the error term. Each genet was considered as a true replicate of the factor sub-population, thus the experiment has a total of three treatments $x$ two sub-populations $x$ six genets $=36$ pots. Data were checked for ANOVA assumptions and were $\log$ transformed when needed.

\section{RESULTS}

The reduction in water availability reduced aboveground biomass for both sub-populations in the same way and thus there was no significant water availability $\mathrm{x}$ sub-population interaction (Fig. 2A). Belowground biomass was not statistically affected by water availability (Fig. 2B). Thus, total biomass followed the same pattern as above ground biomass (Fig. 2C). None of the three variables were statistically affected either by subpopulation main effect or by water availability x sub-population interaction (Fig. 2).
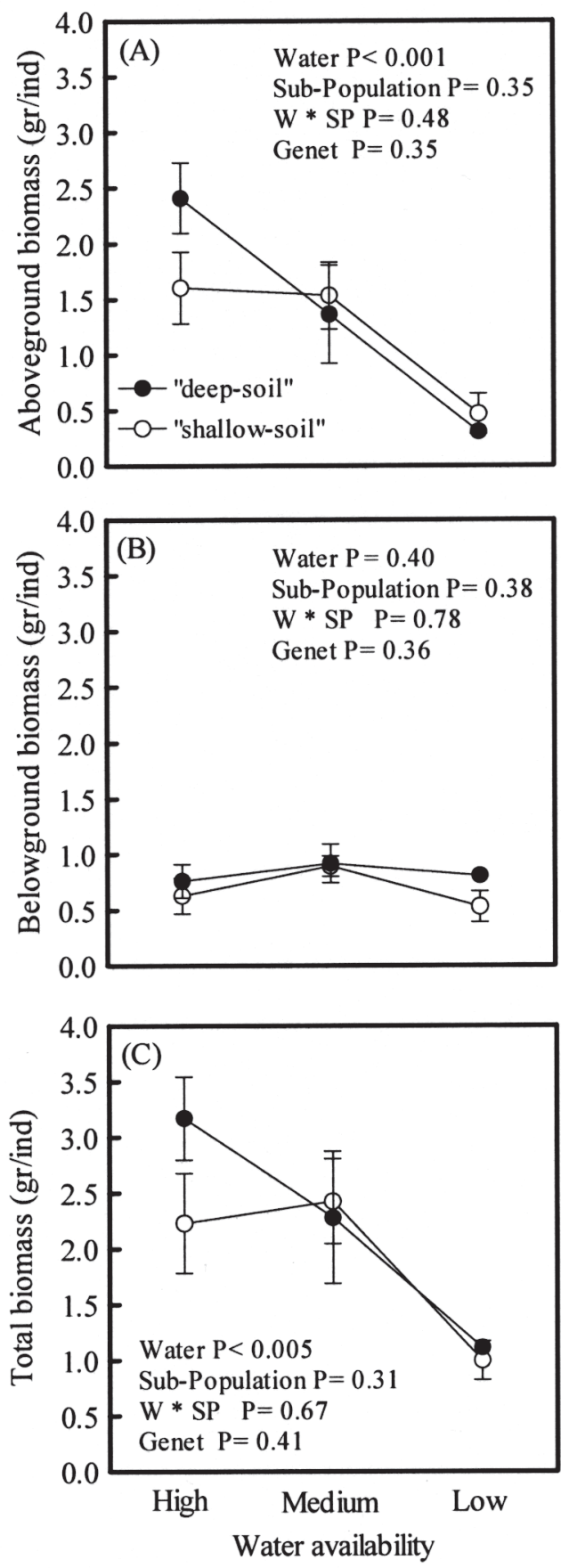

Fig. 2: Effect of drought for two sub-populations of Bromus from "deep-soil" and "shallowsoil" communities across a water availability gradient. Variable responses are (A) aboveground biomass, (B) belowground biomass, and (C) total biomass. Data are means \pm SE.

Efecto de la sequía para dos subpoblaciones de Bromus provenientes de comunidades de "suelos profundos" y "suelos someros" a través de un gradiente de disponibilidad de agua. Las variables de respuesta son (A) biomasa aérea, (B) biomasa subterránea, y (C) biomasa total. Los datos representan medias $\pm \mathrm{EE}$. 
Low water availability also reduced aboveground RGR in both sub-populations (Fig. 3A). Aboveground RGR was, on average, significantly higher in the "deep-soil" than in the "shallow-soil" sub-population (Fig. 3A). Belowground RGR was not significantly affected either by water availability main effect or by sub-population (Fig. 3B). Thus, total RGR followed the same pattern as aboveground RGR, and the effect of sub-population was marginally significant (Fig. 3C). None of these variables were significantly affected by water availability $\mathrm{x}$ sub-population interaction.

Individual leaf area $\left(\mathrm{cm}^{2}\right.$ leaf $\left.{ }^{-1}\right)$ and weight $\left(\mathrm{mg} \mathrm{leaf}^{-1}\right)$ were significantly reduced by low water availability (Fig. 4A and 4B). This effect was the same for the two sub-populations, as indicated by the lack of sub-population by water availability interaction (Fig. 4A and 4B). On average, leaf size (area and weight) was higher in the "deep-soil" sub-population than in the "shallow-soil" population (Fig. 4A and 4B).

Tiller angle was not significantly affected by water availability (Fig. 4C). The "deep-soil" sub-population showed a significantly higher tiller angle respective to soil surface than the "shallow-soil" sub-population (Fig. 4C). This results in a more erect morph of the "deep-soil" sub-population than the "shallow-soil" subpopulation. There was no significant effect of the interaction of water availability by subpopulation.

Tillering rate was marginally reduced by the reduction in water availability (Fig. 4D). Tillering rate was, on average, significantly greater in the "shallow-soil" sub-population than in the "deep-soil" sub-population (Fig. 4D). The interaction of water availability by sub-population was not statistically significant.

\section{DISCUSSION}

Genetic differentiation mainly occurred in morphological variables and in less degree in growth variables. This was shown by the main effect of sub-population in all the morphological variables measured and in only one of the growth variables (aboveground RGR). Also, the effect on aboveground RGR was marginal. The lack of population by water availability interaction indicates that both populations presented the same tolerance to the drought imposed in this study.
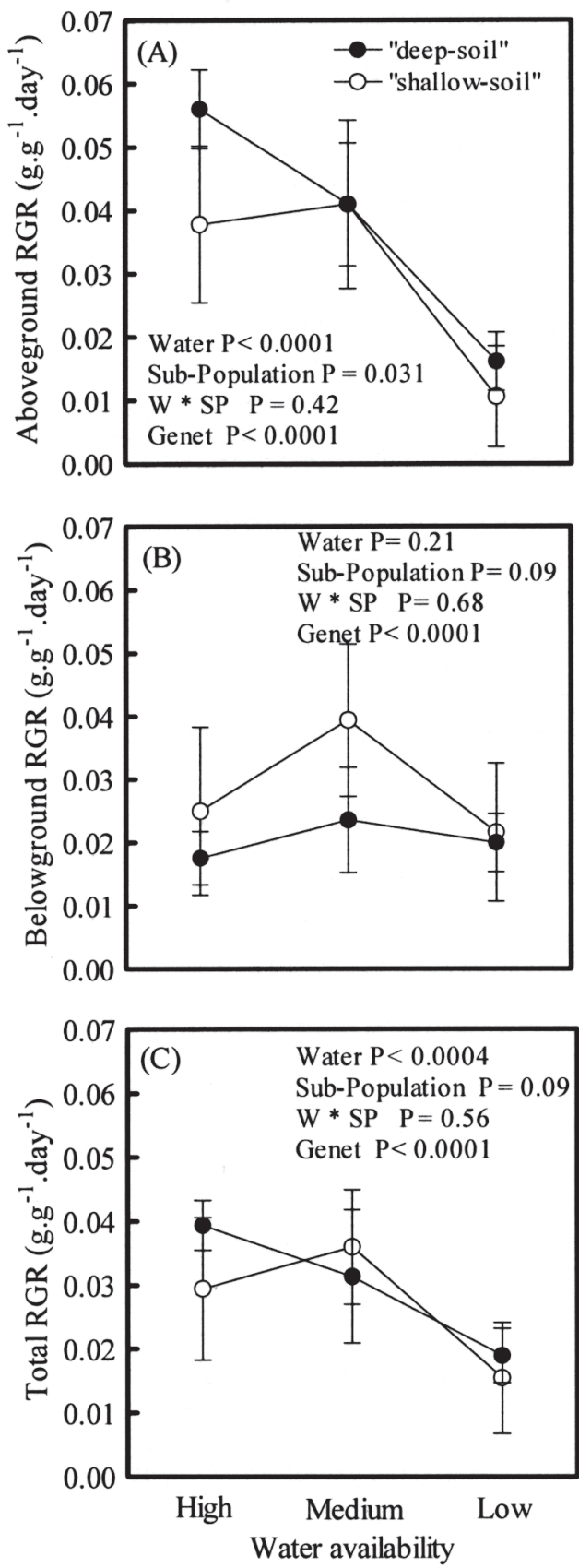

Fig. 3: Effect of drought for two sub-populations of Bromus from "deep-soil" and "shallowsoil" communities across a water availability gradient. Variable responses are (A) aboveground relative growth rate, (B) belowground relative growth rate, and (C) total relative growth rate. Data are means $\pm \mathrm{SE}$.

Efecto de la sequía para dos subpoblaciones de Bromus provenientes de comunidades de "suelos profundos" y "suelos someros" a través de un gradiente de disponibilidad de agua. Las variables de respuesta son (A) tasa aérea de crecimiento relativa, (B) tasa subterránea de crecimiento relativa, y (C) tasa total de crecimiento relativa. Los datos representan medias $\pm \mathrm{EE}$. 
Genetic differentiation can occur when selective pressures overwhelm homogenizing gene flow (Linhart \& Grant 1996, Barton \& Partridge 2000). According to this, there are no physical barriers for gene flow between the two sub-populations. However, two facts may explain low levels of gene flow in our system. First, Bromus is a cleistogamous species (Naranjo et al. 1990) and thus gene flow by pollen between the subpopulations is avoided. Secondly, seed dispersion by wind occurs only at short distances $(<1 \mathrm{~m})$ (M.R. Aguiar unpublished results) which also prevents gene flow between the sub-populations.

Higher RGR is expected to be selected in resource rich environments (Chapin et al. 1993). The results obtained confirm this statement since "deep-soil" sub-population had a marginal higher above RGR than the "shallow-soil" sub- population. Likewise, the "deep-soil" subpopulation had a higher leaf size (area and weight) than the "shallow-soil" sub-population. This result agrees to the theoretical model developed by Givish \& Vermeij (1976) predicting the evolution of optimal leaf size. They proposed that the optimal leaf size maximizes the difference between the benefits of increased photosynthesis and the cost of increased water loss. This optimal leaf size will be smaller under reduced water availability. This pattern has been observed at the inter-specific level along rainfall gradients (Fonseca et al. 2000) and our results support the model at the intra-specific level and within the same regional climate. Parallel to the variation in leaf size that we found, other physiological and anatomical traits may also change (Dong \& Zhang 2001).
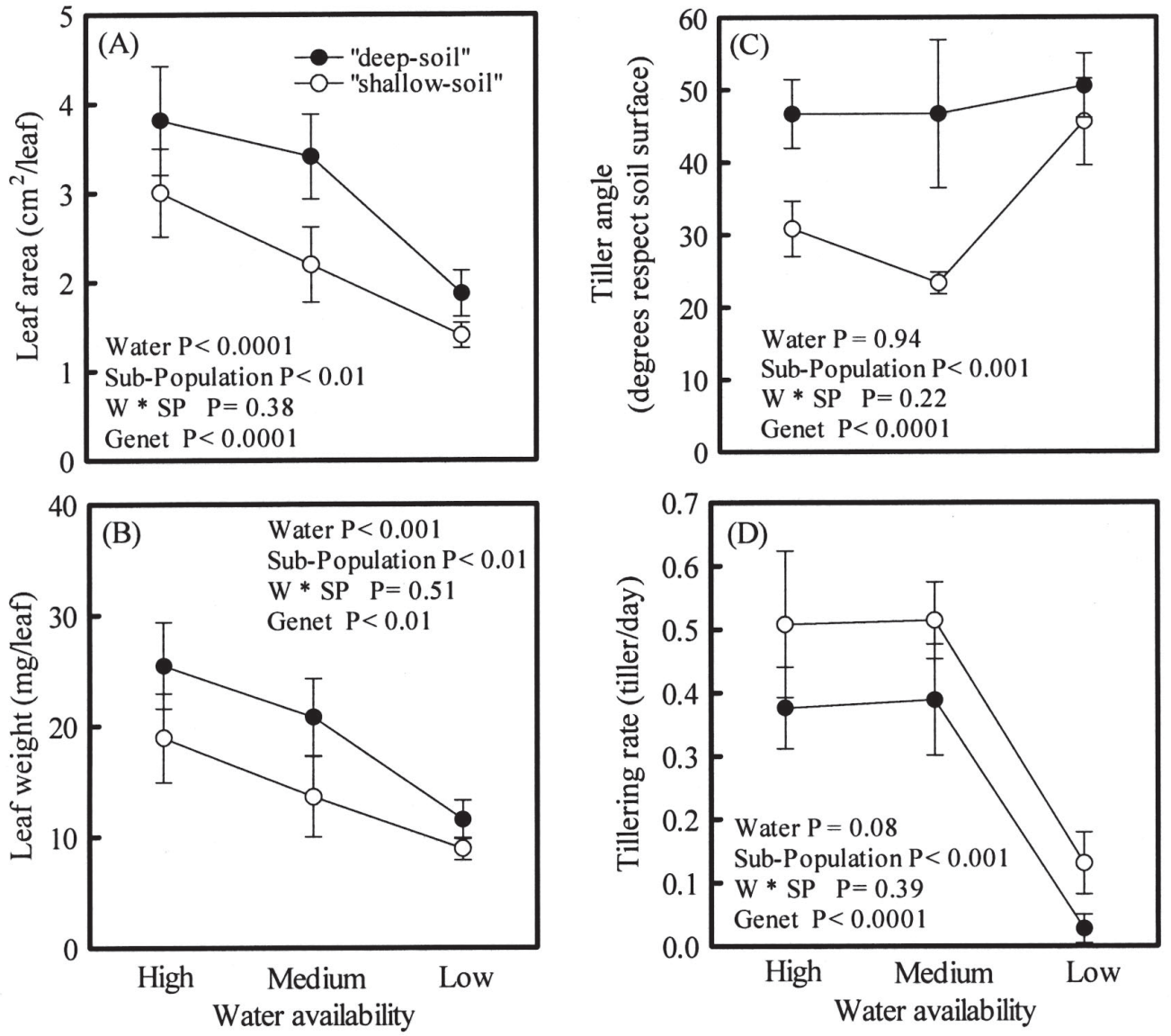

Fig. 4: Effect of drought for two populations of Bromus from "deep-soil" and "shallow-soil" communities across a water availability gradient. Variable responses are (A) leaf area, (B) leaf biomass, (C) tiller angle and (D) tillering rate. Data are means \pm SE.

Efecto de la sequía para dos subpoblaciones de Bromus provenientes de comunidades de "suelos profundos" y "suelos someros" a través de un gradiente de disponibilidad de agua. Las variables de respuesta son (A) área foliar, (B) biomasa foliar, (C) ángulo de inserción de los macollos, y (D) tasa de macollaje. Los datos representan la medias \pm EE. 
The more prostrate morph of the "shallowsoil" sub-population could present advantages in reducing the whole-plant area exposed to dry air. In addition, "shallow-soil" sub-population had higher tillering rate than "deep-soil" population. This negative correlation between tiller number and leaf size was proposed by Gorhan (1979). A higher number of smaller tillers may be a useful strategy to facilitate a quick response to water inputs (Coughenour 1985). This is because there are several growth points that enable the plant to make an efficient use of the short period of water availability. Besides, a high number of small tillers may distribute the risk of drought-induced mortality and may increase the rate of post-defoliation recovery (Coughenour 1985). Most of these attributes present in the "shallow-soil" subpopulation, which would be adaptative in arid habitats, may also be beneficial to overcome grazing (Coughenour 1985). Since overgrazing has lead to local extinction of Bromus in some locations (Aguiar et al. 1999), "shallow-soil" sub-populations may be able to colonize degraded "deep-soil" communities in the long term. This speculation enhanced the importance of knowing the prior differences in the genetic structure in the space to understand the present and future dynamics of these populations.

No statistically significant effect of the interaction of water availability $x$ subpopulation was found for either of the variables measured. Thus, results fit better with the model presented in Fig. 1B, where there are average differences between the subpopulations due to differences in the intercept. However, the expected result that would evidence home-site advantage, and thus genetic differentiation, would be the one presented in Fig. 1C [sub-population 2 ("deep-soil") and sub-population 4 ("shallow-soil")]. A possible explanation of these findings could be that our treatments only manipulate one component of the water cycle, which is water supply and not water demand. In drier conditions (water demand relative to water supply) present in the shallow-soil community compared to the deepsoil community, where atmospheric demand is by far higher than the experimented in the greenhouse, the more postrate and small sized "shallow-soil" sub-population would be more successful than the more erect and high sized "deep-soil" sub-population.
Due to the intrinsic limitations of a greenhouse experiment, it is wise to be cautious when extrapolating these results to field situations. The differentiation measured in the present paper was expressed in a set of environmental conditions that may not be exactly the same experienced by the plants in the field. However, since the effect of soil depth is principally due to reduced water availability, we are confident that the drought treatments employed in this experiment capture what happens in the field in a high degree. Taking the above mentioned limitation into account, the result will be discussed in the context of Bromus reseeding and in the context of global change.

The reseeding of degraded steppes of Patagonia with Bromus would be necessary in order to increase its carrying capacity for sheep production. The availability of improved populations of native plants may foster the revegetation of degraded lands (Jones \& Johnson 1994). Even though native grasses used for revegetation are not improved, domestication (e.g., cultivation and seed harvesting) usually involves a mass selection procedure (Poehlman \& Sleper 1995). Our results showed that within this site, there is genetic variation in traits related to drought resistance that could be target of selection to obtain improved populations. We also speculate that these traits would be useful to overcome the effects of grazing. Since sheep grazing is the main land use of Patagonia these traits may have economic impact.

Human activities are causing environmental changes in a global scale (Vitousek 1994). There is uncertainty about how plant populations will respond to current global changes. Historically, plants have responded to climate change by adaptation or migration (Davis \& Shaw 2001). Some models of evolutionary responses to global climate changes predict that we should expect considerable extinction due to restricted opportunities of migration associated to landscape fragmentation (Bradshaw \& McNeilly 1991). Thus, the primary strategy of species survival may be the evolution of appropriate genotypes based on variation among individuals within the same local population (Etterson \& Shaw 2001). In the Patagonian steppe, the genetic variation promoted by soil heterogeneity would increase the evolutionary potential of Bromus to adapt 
to drier conditions predicted for these sites (Sala 2001). This kind of research will become highly necessary if we want to predict the responses of populations to new climatic or land-use scenarios.

\section{ACKNOWLEDGMENTS}

We thank Esteban Jobbágy for useful comments on an early version of the manuscript. Ruy Perea and Nicolás Trillo helped in the different parts of field and lab work. Instituto Nacional de Técnología Agropecuaria (INTA) granted access to the experimental field and facilities. The studies reported in this manuscript comply with the ethics guidelines and current laws of Argentina. José Luis Rotundo and Pablo Ariel Cippriotti were supported by a doctoral fellowship from Consejo Nacional de Investigaciones Científicas y Técnicas (CONICET) and Pedro Emilio Gundel is supported by Universidad de Buenos Aires.

\section{LITERATURE CITED}

AGUIAR MR \& OE SALA (1999) Patch structure, dynamics and implications for the functioning of arid ecosystems. Trends in Ecology and Evolution 14: 273-277.

BARTON N \& L PARTRIDGE (2000) Limits to natural selection. BioEssays 22: 1075-1084.

BELTRÁN A (1997) Caracterización microclimática del distrito occidental de la estepa patagónica. Magister Thesis, Universidad de Buenos Aires, Argentina. $119 \mathrm{pp}$.

BRADSHAW A \& T McNEILLY (1991) Evolutionary response to global climatic change. Annals of Botany 67: 5-14.

CHAPIN III F, K AUTUMN \& F PUGNAIRE (1993) Evolution of suites of traits in response to environmental stress. American Naturalist 142: s78s92.

COUGHENOUR MB (1985) Graminoid responses to grazing by large herbivores: adaptations, exaptations, and interacting processes. Annals of the Missouri Botanical Garden 72: 852-863.

DAVIS MB \& RG SHAW (2001) Range shifts and adaptive responses to quaternary climate change. Science 292: 673-679.

DONG X \& X ZHANG (2001) Some observations of the adaptations of sandy shrubs to the arid environment in the $\mathrm{Mu}$ Us sandland: leaf water relations and anatomic features. Journal of Arid Environments 48: 41-48.

ENDLER JA (1986) Natural selection in the wild. Princeton University Press, Princeton, New Jersey, USA. 336 pp.

ETTERSON JR \& RG SHAW (2001) Constraint to adaptive evolution in response to global warming.
Science 294: 151-154.

FERNÁNDEZ ARJ, OE SALA \& RA GOLLUSCIO (1991) Woody and herbaceous aboveground production of a Patagonian steppes. Journal of Range Management 44: 434-737.

FONSECA C, J McCOVERTON, B COLLINS \& M WESTOBY (2000) Shifts in trait combinations along rainfall and phosphorus gradients. Journal of Ecology 88: 964-977

GIVNISH TJ \& GJ VERMEIJ (1976) Size and shapes of liane leaves. American Naturalist 110: 743-778.

GOLLUSCIO RA \& OE SALA (1993) Plant functional types and ecological strategies in Patagonian forbs. Journal of Vegetation Science 4: 839-846.

GOLLUSCIO RA, RJC LEÓN \& SB PERELMAN (1982) Caracterización fitosociológica de la estepa del oeste del Chubut: su relación con el gradiente ambiental. Boletín de la Sociedad Argentina de Botánica 21: 299-324.

GOLLUSCIO RA, JM PARUELO, JL MERCAU \& VA DEREGIBUS (1998) Urea supplementation effects on the utilization of low-quality forage and lamb production in Patagonian rangelands. Grass and Forage Science 53: 47-56.

GOLLUSCIO RA, JM PARUELO \& VA DEREGIBUS (1999). Pastoreo con descansos en la Patagonia: desarrollo de un paquete tecnológico. Revista Argentina de Producción Animal 19: 89-102.

GORHAN E (1979) Shoot height, weight and standing crop in relation to density of monospecific stands. Nature 279: 148-150.

HOCHWENDER CG, RJ MARQUIS \& KA STOWE (2000) The potential for and constraints on the evolution of compensatory ability in Asclepias syriaca. Oecologia 122: 361-370.

HUNT R (1990) Basic growth analysis. Unwin Hyman Ltd., London, United Kingdom. 112 pp.

INFOSTAT v1.0 (2001) Departamento de Estadística y Biometría, Facultad de Ciencias Agropecuarias, Universidad Nacional de Córdoba. Website: infostat@agro.uncor.edu

JOBBÁGY EG \& OE SALA (2000) Controls of grass and shrub aboveground production in the Patagonian steppe. Ecological Applications 10: 541-549.

JOBBÁGY EG, JM PARUELO \& RJC LEÓN (1995) Estimación de la precipitación a partir de la distancia a la cordillera en el noroeste de la Patagonia. Ecología Austral (Argentina) 5: 47-53.

JONES TA \& DA JOHNSON (1994) Integrating genetics concepts into planning rangeland seedings. Journal of Range Management 51: 594-606.

LEÓN RJC, D BRAN, M COLLANTES, JM PARUELO \& A SORIANO (1998) Grandes unidades de vegetación de la Patagonia extrandina. Ecología Austral (Argentina) 8: 125-144.

LINHART YB \& MC GRANT (1996) Evolutionary significance of local genetic differentiation in plants. Annual Review of Ecology and Systematics 27: 237-277.

M'SEDDI K, M VISSER, M NEFFATI, D REHEUL \& M CHAIEB (2002) Seed and spike traits from remnant populations of Cenchrus ciliaris L. in south Tunisia: high distinctiveness, no ecotypes. Journal of Arid Environments 50: 309-324.

MONTGOMERY DC (1997) Design and analysis of experiments. Fourth edition. John Wiley \& Sons, New York, New York City, USA. 704 pp.

NARANJO CA, FH ARIAS \& A SORIANO (1990) Bromus pictus of the B. setifolius complex (section Pnigma), numerical taxonomy and chromosome 
evidence for species rank. Canadian Journal of Botany 68: 2493-2500.

PARUELO JM, RA GOLLUSCIO \& MR AGUIAR (1988) Soil water availability in the Patagonian arid steppe: gravel content effect. Arid Soil Research and Rehabilitation 2: 67-74.

POEHLMAN JM \& DA SLEPER (1995) Breeding field crops. Fourth edition. Iowa State University Press, Ames, Iowa, USA. 495 pp.

SALA OE (2001) Temperate Grasslands. In: Chapin FS, Sala OE \& E Huber-Sannwald (eds) Global biodiversity in a changing environment: scenarios for the 21st century: 121-137. Springer Verlag, New York, New York, USA.

SARKAR S \& T FULLER (2003) Generalized norms of reaction for ecological development biology. Evolution \& Development 5: 106-115.

SILVERTOWN JW \& JL DOUST (1993) Introduction to plant population biology. Blackwell Science Ltd., Cambridge, United Kingdom. 202 pp.

SORIANO A (1983) Deserts and semi-deserts of Patagonia. In: West $\mathrm{N}$ (ed) Temperate deserts and

Associate Editor: Luis Corcuera

Received May 5, 2005; accepted October 18, 2005 semi-deserts: 423-460. Elsevier, Amsterdam, The Netherlands.

SORIANO A, RA GOLLUSCIO \& EH SATORRE (1987)

Spatial heterogeneity of the root system of grasses in the Patagonian arid steppe. Bulletin of the Torrey Botanical Club 114: 103-108.

SORIANO A, OE SALA OE \& SB PERELMAN (1994) Patch structure and dynamics in a Patagonian arid steppe. Vegetatio 111: 127-135.

STOWE KA, RJ MARQUIS, CG HOCHWENDER \& EL SIMMS (2000) The evolutionary ecology of tolerance to consumer damage. Annual Review of Ecology and Systematics 31: 565-595.

SULTAN SE (2000) Phenotypic plasticity for plant development, function and life history. Trends in Plant Science 5: 537-542.

THEUNISSEN JD (1997) Selection of suitable ecotypes within Digitaria eriantha for reclamation and restoration of disturbed areas in southern Africa. Journal of Arid Environments 35: 429-439.

VITOUSEK PM (1994) Beyond global warming: ecology and global change. Ecology 75: 1861-1876. 